\title{
Editorial: Hermenêuticas do Feminino
}

\author{
Editorial: \\ Hermeneutics of the Feminine
}

Maria Clara Lucchetti Bingemer

A mulher em nossos dias vem deixando o âmbito doméstico para participar do espaço público desejando uma convivência em igualdade de direitos com o homem. Entretanto ainda se percebe presente a visão masculina patriarcal como predominante e muitas vezes expressando-se em termos de dominação. As novas reivindicações trazidas pelas mulheres têm sido dificilmente aceitas nos segmentos sociais que frequentemente reagem com um aumento da violência contra a mulher.

Uma análise do contexto brasileiro e latino-americano, e até mesmo mundial, leva-nos a perceber que existe no centro da chamada "violência de gênero" o fator cultural e social que afirma ser a mulher inferior ao homem. A introjeção da superioridade do modelo masculino, o mimetismo de ação que foi padrão em relação às gerações anteriores traz a violência como um mecanismo que é fruto de um padrão familiar de subordinação e de um não questionamento das imposições masculinas. Assim, o modelo familiar predominante é o da autoridade paterna, o que determina a submissão não só dos filhos, mas igualmente da mulher a essa autoridade.

Embora a sociedade venha passando por modificações em relação à liberdade da mulher e à conscientização do patriarcalismo, nas relações estabelecidas entre homens e mulheres, de modo geral, ainda são os homens que assumem o poder sobre as mulheres, pois a supremacia masculina é introjetada por ambos, privilegiando uns em detrimento das outras. Dessa forma, quando a mulher não aceita como "natural" o papel a ela imposto, é comum os homens recorrerem à violência, desde as formas mais sutis (psicológica, patrimonial) à 
violência física, podendo chegar ao assassinato. Não à toa, durante a pandemia do novo Coronavírus, o número de feminicídios aumentou exponencialmente.

Se assim é na sociedade, a situação nas igrejas tampouco é muito diferente. Depois do Concílio Vaticano II, no entanto, percebem-se alguns movimentos transformadores. Inicialmente os ventos de mudança no processo de consciência e emancipação das mulheres no Ocidente cristão, e na América Latina em particular, não sopraram dentro das igrejas. Vieram de um processo de secularização através de lutas concretas e mundanas, por assim dizer "profanas" (o direito de votar, salários, horas de trabalho, sexualidade e direitos do corpo). Por meio dessas lutas, as mulheres começaram a se liberar do espaço doméstico privado, onde haviam sido confinadas, e a passar para o espaço público, como agentes políticas nas estruturas sociais de mudança e na produção econômica e cultural.

A voz das mulheres, ouvida nas comunidades cristãs latino-americanas, remonta a pouco mais de cinco décadas. A partir do Concílio, mulheres passaram a coordenar comunidades em diferentes níveis, questionaram a negação do acesso feminino aos diferentes ministérios eproduziram reflexões teóricas sobre a experiência religiosa e os conteúdos doutrinais da fé cristã. $\mathrm{E}$ o fato é que hoje é impossível pensar o futuro do cristianismo ou fazer teologia sem levar em consideração a contribuição feminina.

O pensar feminino e o pensar sobre o feminino assumem hoje, no entanto, diferentes ângulos interpretativos para construir sua reflexão. Existem, na verdade, na Teologia e nas diferentes Ciências Humanas e Sociais distintas hermenêuticas do feminino. Entre estas destacam-se as áreas de pesquisa da Sociologia, da Filosofia, da Literatura, da História e também e não menos da Exegese Bíblica, das Ciências da Religião e da Teologia.

Este número da revista Atualidade Teológica traz aos leitores algumas destas hermenêuticas. Desde leituras acuradas do feminino na Bíblia, passando por histórias de vida onde esse mesmo feminino se destaca, em termos de atuação na sociedade ou de experiências místicas profundas e desconcertantes, não deixando de lado a reflexão sistemática sobre Maria, a mãe de Jesus.

Inclui também uma resenha detalhada e instigante sobre o recente colóquio acontecido na PUC-Campinas a respeito da proximidade da problemática feminina com a ecológica. Pesquisadores de diferentes áreas do saber se encontraram para dialogar e debater sobre os ecos que as hermenêticas do feminino têm na Casa Comum, que é a terra, sobre a qual o Papa Francisco chama a atenção em sua encíclica Laudato Si’ de 2015. 
Transformar a Igreja e a sociedade em feminino parece ser tarefa urgente. O presente número da revista do Programa de Pós-Graduação do Departamento de Teologia da PUC-Rio demonstra com este dossiê estar comprometido com tal tarefa.

\section{Maria Clara Lucchetti Bingemer}

Doutora em Teologia pela Pontificia Università Gregoriana Docente do Departamento de Teologia da Pontifícia Universidade Católica do Rio de Janeiro Rio de Janeiro / RJ - Brasil E-mail: agape@puc-rio.br 